\title{
Preferential Localization of Systemically Administered Radiolabeled Interleukin $1 \alpha$ in Experimental Inflammation in Mice by Binding to the Type II Receptor
}

\author{
Conny J. van der Laken, ${ }^{\star}$ Otto C. Boerman, ${ }^{\star}$ Wim J.G. Oyen, ${ }^{\star}$ Marjo T.P. van de Ven, ${ }^{\star}$ Richard Chizzonite, ${ }^{\S}$ \\ Frans H.M. Corstens, ${ }^{*}$ and Jos W.M. van der Meer ${ }^{\ddagger}$ \\ *Department of Nuclear Medicine and ${ }^{\ddagger}$ Department of Internal Medicine, University Hospital Nijmegen, 6500 HB Nijmegen, \\ The Netherlands; and ${ }^{\S}$ Department of Inflammation/Autoimmune Diseases, Hoffmann-LaRoche Inc., Nutley, New Jersey 07110-1199
}

\begin{abstract}
Previously, we have shown that systemically administered radiolabeled interleukin $1 \alpha$ (IL-1 $\alpha)$ accumulates preferentially in inflammatory foci in mice. Since inflammation is characterized by influx of leukocytes, which represent IL-1 receptor (IL-1R) positive cells, radiolabeled IL-1 may specifically localize in inflammation by binding to its receptors on infiltrated leukocytes. This hypothesis was tested in a series of studies in mice with acute focal inflammations. Evidence for specific IL-1-IL-1R interaction in induced inflammation was found: microscopic autoradiography revealed that ${ }^{125} \mathrm{I}-\mathrm{IL}-1 \alpha$ localized at the site of inflammatory cells with time; ${ }^{125}$ I-myoglobin, a similar-sized protein with no known interactions in vivo, was not retained in the inflammation. Furthermore, the uptake ${ }^{125} \mathrm{I}-\mathrm{IL}-1 \alpha$ in inflammatory tissue was significantly lower in neutropenic mice than in immunocompetent mice $(0.05 \pm 0.004$ vs. $0.65 \pm 0.06 \% \mathrm{ID} / \mathrm{g}$ at $48 \mathrm{~h}$ after injection, $P<\mathbf{0 . 0 0 0 7 )}$. Moreover, the uptake of ${ }^{125}$ I-IL-1 $\alpha$ at the inflammatory site could be blocked with the anti-IL-1R type II antibody 4E2. At $48 \mathrm{~h}$ after injection, the uptake with and without blocking the type II IL-1R was $0.13 \pm 0.01$ and $0.65 \pm 0.05 \% \mathrm{ID} / \mathrm{g}$, respectively $(P<0.0001)$. These in vivo studies provide evidence that systemically administered radiolabeled IL- $1 \alpha$ localizes in inflammatory tissue by specific receptor binding, predominantly by binding to the type II IL-1R. (J. Clin. Invest. 1997. 100:2970-2976.) Key words: leukocytic infiltration $\bullet$ mice $\bullet$ microscopic autoradiography $\bullet$ neutropenia $\bullet$ receptor blockade
\end{abstract}

\section{Introduction}

IL-1 is a 17-kD protein, produced by monocytes as a response to endotoxin. Two forms of IL-1, IL- $1 \alpha$ and IL-1 $\beta$, have been discovered, binding to two types of receptors on a wide variety of cells. The type I IL-1 receptor (IL-1R), a $80-\mathrm{kD}$ glycoprotein, is found on T cells, fibroblasts, hepatocytes, and endothe-

Address correspondence to Conny J. van der Laken, M.D., Department of Nuclear Medicine, University Hospital Nijmegen, P.O. Box 9101, 6500 HB Nijmegen, The Netherlands. Phone: 31-24-3613813; FAX: 31-24-3618942; E-mail: J.vanderLaken@Nugen.AZN.NL

Received for publication 20 June 1997 and accepted in revised form 9 October 1997.

J. Clin. Invest.

(C) The American Society for Clinical Investigation, Inc. 0021-9738/97/12/2970/07 \$2.00

Volume 100, Number 12, December 1997, 2970-2976

http://www.jci.org lial cells, whereas B cells, macrophages, monocytes, and neutrophils express the $68-\mathrm{kD}$ type II IL-1R (1). IL-1 binds to both receptors with affinity in the picomolar range (2).

Since infection and inflammation are characterized by influx of predominantly IL-1R positive leukocytes, systemically administered IL-1 may preferentially localize in inflammatory tissue by means of specific receptor binding. Recently, localization of radiolabeled IL-1 $\alpha$ in Staphylococcus aureus-induced infections in mice was demonstrated (3). It cleared rapidly from noninflamed tissues.

Receptor binding of IL-1 to murine leukocytes has been well characterized both in vitro and ex vivo $(2,4,5)$. However, in vivo in mice, receptor binding has not been demonstrated directly but only indirectly via inhibition of IL-1-induced biologic activity by blockade of type I IL-1Rs (6-10). In vivo binding to type II IL-1Rs could not be shown due to lack of effect of type II IL-1R blockade on biologic activity (10). The present paper describes a series of studies conducted to validate the hypothesis of specific receptor binding of IL-1 $\alpha$ in inflammation in mice. Binding of systemically administered IL- $1 \alpha$ to type I as well as type II IL-1Rs was investigated by antibody-blocking studies. Our studies demonstrate localization of IL- $1 \alpha$ in inflammatory tissue by specific binding to type II IL-1Rs on locally present infiltrated leukocytes.

\section{Methods}

Mice. Female Swiss mice weighing 20-25 g (Harlan Netherlands B.V., Zeist, The Netherlands) were kept in cages (5-15 mice per cage) and fed standard laboratory chow and water ad libitum.

Reagents. Human recombinant IL-1 $\alpha$ (specific activity of $3 \times 10^{8}$ $\mathrm{U} / \mathrm{mg}$ ) was kindly provided by Dr. P. Lomedico (Hoffman-La Roche, Nutley, NJ). Myoglobin was purchased from Sigma Chemical Co. (St. Louis, MO). The anti-IL-1R type I antibody (35F5) and the anti-IL-1R type II antibody (4E2) (both monoclonal rat $\mathrm{IgG}$ ) were prepared at Hoffmann-LaRoche.

Radioiodination. IL- $1 \alpha$ and IL-1 $\beta$ were radiolabeled using the iodogen method (11). In brief, for microscopic autoradiography studies, $10 \mu \mathrm{g} \mathrm{IL}-1 \alpha(0.68 \mathrm{mg} / \mathrm{ml})$ in $10 \mu \mathrm{l} 0.5 \mathrm{M}$ and $80 \mu \mathrm{l} 50 \mathrm{mM}$ phosphate buffer, $\mathrm{pH} 7.2$, and $111 \mathrm{MBq} \mathrm{Na}{ }^{125}$ I (Amersham International, Amersham, UK; specific activity of $570 \mathrm{GBq} / \mathrm{mg}$ ) were added to glass tubes, precoated with $25 \mu \mathrm{g}$ of 1,3,4,6-tetrachloro-3 $\alpha, 6 \alpha$-diphenylglucouril (Pierce, Rockford, IL). For all other studies, $3 \mu \mathrm{g}$ IL- $1 \alpha(0.68$ $\mathrm{mg} / \mathrm{ml})$ or $3 \mu \mathrm{g}$ IL-1 $(1 \mathrm{mg} / \mathrm{ml})$ was labeled with $15-20 \mathrm{MBq} \mathrm{Na}^{125} \mathrm{I}$. The reaction was allowed to proceed for $10 \mathrm{~min}$ at room temperature, after which the reaction mixture was eluted with $0.5 \%$ BSA in PBS on a Sephadex column (PD-10; Pharmacia, Uppsala, Sweden) to separate labeled IL- $1 \alpha$ and IL- $1 \beta$ from free ${ }^{125}$ I. The void fractions were pooled and sterilized through a $0.2-\mu \mathrm{m}$ filter.

Analogously, $10 \mu \mathrm{g}$ myoglobin $(1 \mathrm{mg} / \mathrm{ml})$, a protein with a molecular mass $(18 \mathrm{kD})$ similar to IL- $1 \alpha$ and IL- $1 \beta$ without any known interactions in vivo, was labeled with $\mathrm{Na}^{125} \mathrm{I}$.

The labeling efficiency of IL- $1 \alpha$, IL- $1 \beta$, and myoglobin was between 50 and $80 \%$. For the microscopic autoradiography studies, 
both IL-1 $\alpha$ and myoglobin were labeled with $\mathrm{Na}^{125} \mathrm{I}$ at a specific activity of $8-12 \mathrm{MBq} / \mu \mathrm{g}$. The specific activity used in all other studies was 3-4 MBq/ $\mu \mathrm{g}$.

The radiochemical purity of the radiolabeled proteins was determined by instant thin-layer chromatography (ITLC) on Gelman ITLC-SG strips (Gelman Laboratories, Ann Arbor, MI) with $0.1 \mathrm{M}$ citrate, $\mathrm{pH} 5.0$, as the solvent. The radiochemical purity of all radiolabeled proteins was $>96 \%$ after removal of unbound iodine.

Typically, the receptor binding fraction and the dissociation constant of radioiodinated IL-1 preparations were $70-95 \%$ and $5 \times 10^{-11}$ $\mathrm{mol} /$ liter, respectively, as determined on the murine cell line EL-4-6.1, a variant subline of EL-4 thymoma cells (12), a kind gift of Dr. H.R. MacDonald (Ludwig Institute for Cancer Research, Epalinges, Switzerland) (3).

Mouse model of inflammation. Focal inflammations in the left calf muscles of ether anesthetized mice were induced either with $2 \times$

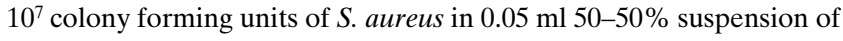
autologous blood and normal saline or with $0.05 \mathrm{ml} 7.5 \%$ zymosan in sterile saline. In some experiments, before the induction of focal inflammation (day 0$)$, neutropenia $\left(<10^{9}\right.$ white blood cells/liter) was induced in mice by repeated subcutaneous injections of cyclophosphamide: $150 \mathrm{mg} / \mathrm{kg}$ body wt in $200 \mu \mathrm{l}$ saline on day -4 and $100 \mathrm{mg} /$ $\mathrm{kg}$ on day $-1.24 \mathrm{~h}$ after the induction of inflammation, when swelling of the muscle was apparent, mice were injected with ${ }^{125} \mathrm{I}-\mathrm{IL}-1 \alpha,{ }^{125} \mathrm{I}-$ IL-1 $\beta$, free ${ }^{125} \mathrm{I}$, or with the nonspecific control agent ${ }^{125} \mathrm{I}$-myoglobin (microscopic autoradiography) in the tail vein.

Microscopic autoradiography. At 2, 6, and $24 \mathrm{~h}$ after intravenous injection of $0.2 \mathrm{ml} 2 \mu \mathrm{g} 24 \mathrm{MBq}{ }^{125} \mathrm{I}$-IL- $1 \alpha$ or $2 \mu \mathrm{g} 24 \mathrm{MBq}{ }^{125}$ I-myoglobin ( $24 \mathrm{~h}$ after injection only), groups of three mice were killed under ether anesthesia by cervical dislocation. S. aureus-induced inflammations and contralateral noninflamed calf muscles were dissected. After removal, excised tissues were immediately fixed in $4 \%$ buffered formalin and embedded in paraffin. Four sections of $4 \mu \mathrm{m}$ were cut of each excised tissue and mounted on glass slides by conventional procedures. The sections were deparaffinized with xylene and hydrated by passage through serial dilutions of ethanol. Subsequently, slides were dipped in hypercoat LM1 photographic emulsion (Amersham) in the dark room. The slides were exposed in light-tight boxes for 3-4 wk at $4^{\circ} \mathrm{C}$. After exposure, the emulsions were developed with Kodak D-19 developer (4 min), washed in water (20 s), and fixed in $24 \%$ thiosulfate ( $\mathrm{wt} / \mathrm{vol}, 4 \mathrm{~min}$ ). The slides were slightly poststained with hematoxylin. Parallel series of slides stained with hematoxylin and eosin without photographic emulsion were included for better appreciation of morphology.

The autoradiographs were quantitated by automated image anal- ysis (13). 10 high power fields per inflammation section, i.e., 5 fields in the area of the cellular infiltration and 5 fields in the area of the unaffected muscle, were selected. Furthermore, five fields per contralateral muscle were selected. The number of grains per field was determined. The mean number of grains per field was calculated for the different areas in the tissue.

Ex vivo tissue biodistribution. Mice were killed under ether anesthesia by cervical dislocation at $5 \mathrm{~min}, 1,2,6,12,24$, and $48 \mathrm{~h}$ after injection of ${ }^{125} \mathrm{I}-\mathrm{IL}-1 \alpha,{ }^{125} \mathrm{I}-\mathrm{IL}-1 \beta$, or free ${ }^{125} \mathrm{I}$. Blood samples, inflamed left calf muscle, right calf muscle, thymus, lungs, spleen, liver, and kidneys were collected. The dissected tissues were weighed and counted in the gamma counter. To correct for radioactive decay, injection standards were counted simultaneously. The measured radioactivity in tissues and samples was expressed as percentage of injected radioactivity dose per gram of tissue (\% ID/g).

Statistical analysis. All values are expressed as mean \pm SEM. Statistical analysis was performed using the one-way ANOVA.

\section{Results}

The uptake of ${ }^{125} I-I L-1 \alpha$ in inflammation in the course of time. The blood clearance and uptake in inflammation of ${ }^{125} \mathrm{I}-\mathrm{IL}-1 \alpha$ and free ${ }^{125}$ I was determined in mice with $S$. aureus-induced inflammation at various time points $(n=5$ for each preparation per time point) after intravenous injection of $0.4 \mathrm{MBq} 120 \mathrm{ng}$ of ${ }^{125} \mathrm{I}-\mathrm{IL}-1 \alpha$ or $0.4 \mathrm{MBq}$ of free ${ }^{125} \mathrm{I}$. Despite rapid clearance from the blood, ${ }^{125} \mathrm{I}$-IL- $1 \alpha$ accumulated in the inflammation, reaching maximum values of uptake within $2 \mathrm{~h}$ after injection (Fig. $1 A$ ). $2 \mathrm{~h}$ after injection, the uptake of ${ }^{125} \mathrm{I}-\mathrm{IL}-1 \alpha$ in inflammation decreased. A significant level of ${ }^{125}$ I-IL- $1 \alpha$ was retained in the inflammatory tissue up to $48 \mathrm{~h}$ after injection $(0.8 \% \mathrm{ID} / \mathrm{g})$. In contrast, ${ }^{125} \mathrm{I}-\mathrm{IL}-1 \alpha$ levels in the blood continuously decreased to a level $<0.05 \%$ ID/g at $48 \mathrm{~h}$ after injection. $12 \mathrm{~h}$ after injection, the uptake of ${ }^{125} \mathrm{I}$-IL- $1 \alpha$ in inflammation was significantly higher than the blood levels $(P<0.005)$. The retention of activity in inflammation with time was due to uptake of ${ }^{125} \mathrm{I}-\mathrm{IL}-1 \alpha$ and not of free ${ }^{125} \mathrm{I}$ :free ${ }^{125} \mathrm{I}$ rapidly cleared from the inflammation in a similar fashion as from the blood (Fig. $1 \mathrm{~B}$ ). To be able to study the specific receptor-binding mechanism of ${ }^{125}$ I-IL-1 in inflammation, the following studies focused on the time span of 12-48 h after injection because of high background activity levels at early time points.

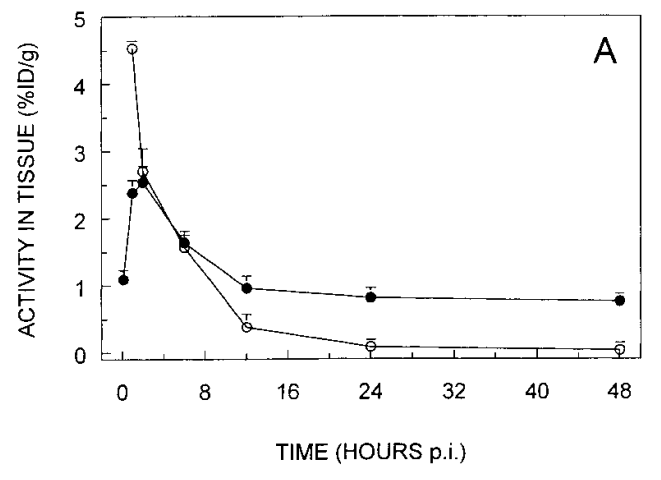

TIME (HOURS p.i.)

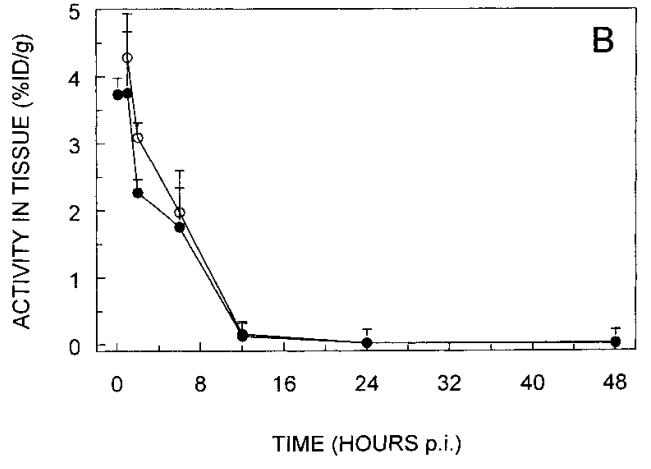

B pressed as percentages of injected radioactivity dose per gram of tissue (\% ID/g). The error bars indicate SEM. The blood levels of both ${ }^{125} \mathrm{I}-\mathrm{IL}-1 \alpha$ and free ${ }^{125} \mathrm{I}$ determined at $5 \mathrm{~min}$ after injection, $6.6 \pm 0.2$ and $8.8 \pm 0.3 \%$ ID/g, respectively, were left out of the figure for clarity. 


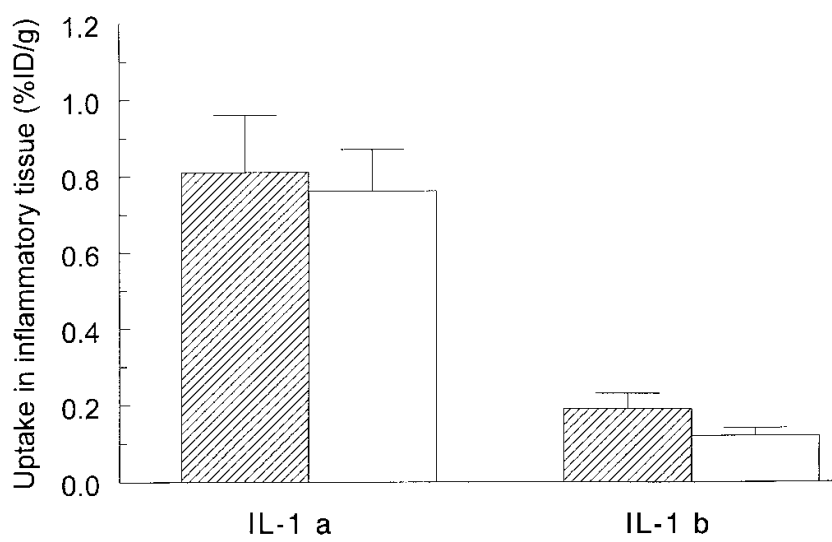

Figure 2. The uptake of ${ }^{125}$ I-IL- $1 \alpha$ and ${ }^{125}$ I-IL-1 $\beta$ in S. aureusinduced inflammation in mice at 24 (striped bars) and $48 \mathrm{~h}$ (open bars) after injection. The results are expressed as percentages of injected radioactivity dose per gram of tissue (\% ID/g). The error bars indicate SEM.

Comparison of uptake of ${ }^{125} I-I L-1 \alpha$ and ${ }^{125} I-I L-1 \beta$ in inflammation. The biodistribution of both ${ }^{125}$ I-IL- $1 \alpha$ and ${ }^{125}$ I-IL-1 $\beta$ was determined in mice with $S$. aureus-induced inflammations at various time points ( $n=5$ for each radiolabeled preparation per time point) after intravenous injection of $0.4 \mathrm{MBq} 120 \mathrm{ng}$ of the radiolabeled preparation. The uptake of ${ }^{125} \mathrm{I}-\mathrm{IL}-1 \alpha$ in inflammation was higher than of ${ }^{125} \mathrm{I}-\mathrm{IL}-1 \beta$ (Fig. 2). At $48 \mathrm{~h}$ after injection, $0.76 \pm 0.11 \% \mathrm{ID} / \mathrm{g}$ of ${ }^{125} \mathrm{I}-\mathrm{IL}-1 \alpha$ was still found in the inflammation, while levels of ${ }^{125}$ I-IL-1 $\beta$ decreased to $0.15 \pm$ $0.01 \% \mathrm{ID} / \mathrm{g}$ at $48 \mathrm{~h}$ after injection. From $12 \mathrm{~h}$ after injection onwards the uptake of ${ }^{125} \mathrm{I}-\mathrm{IL}-1 \alpha$ at the site of inflammation was significantly higher than of ${ }^{125}$ I-IL-1 $\beta(P<0.05)$. Due to the significantly higher uptake of ${ }^{125} \mathrm{I}-\mathrm{IL}-1 \alpha$ in inflammation as compared with ${ }^{125}$ I-IL-1 $\beta$, further studies exploring the receptor-binding mechanism at the inflammatory site were performed with IL-1 $\alpha$.

Microscopic autoradiography. Microscopic autoradiography was applied to study whether systemically administered radiolabeled IL-1 $\alpha$ localizes at the site of infiltrated leukocytes in induced inflammation in mice. As early as $2 \mathrm{~h}$ after injection, uptake of ${ }^{125} \mathrm{I}-\mathrm{IL}-1 \alpha$ in the inflammation was observed. At this time point, most of ${ }^{125} \mathrm{I}-\mathrm{IL}-1 \alpha$, found in areas of cellular infiltration, was localized around the blood vessels. The radiolabel was also found in the unaffected muscular tissue. With time, ${ }^{125} \mathrm{I}-\mathrm{IL}-1 \alpha$ was retained within the cellular infiltration, while the uptake in the unaffected muscle tissue decreased. After $24 \mathrm{~h}$, nearly all ${ }^{125} \mathrm{I}-\mathrm{IL}-1 \alpha$ was clearly associated with the site of inflammatory cells, as demonstrated in Fig. 3, $A$ and $B$. In contrast, no specific retention of ${ }^{125}$ I-IL-1 $\alpha$ was found in the contralateral muscle (Fig. $3 C$ ). The size-matched control protein ${ }^{125}$ I-myoglobin did not localize at the site of the inflammatory cells (Fig. $3 \mathrm{D})$.

The above observations were analyzed quantitatively. The results are shown in Fig. 4. As early as $2 \mathrm{~h}$ after injection, most ${ }^{125} \mathrm{I}-\mathrm{IL}-1 \alpha$ was found in the area of the cellular infiltration at $2 \mathrm{~h}$ after injection. The number of grains in the contralateral muscle and in areas of unaffected muscular tissue in the inflammation decreased during the time course of the experiment. Thus, with time, ${ }^{125}$ I-IL- $1 \alpha$ migrated from the unaffected muscle tissue to the inflammatory cells within the inflammation. After $24 \mathrm{~h}$, nearly all grains in the infection were found in the area of cellular infiltration. At all time points, the number of grains in the cellular infiltration was significantly higher than the number of grains in the adjacent unaffected muscle and the contralateral muscle $(P<0.0001)$. Furthermore, the uptake of ${ }^{125} \mathrm{I}-\mathrm{IL}-1 \alpha$ in the area of the cellular infiltration was significantly higher than of ${ }^{125} \mathrm{I}$-myoglobin at $24 \mathrm{~h}$ after injection $(P<0.0001)$.

Comparison of biodistribution of ${ }^{125} I-I L-1 \alpha$ in immunocompetent and neutropenic mice. To study whether the presence of cellular infiltration is crucial to localization of radiolabeled IL-1 $\alpha$ in inflammation, effects of neutropenia were investigated and compared with observations in immunocompetent mice. Zymosan, instead of $S$. aureus, was used for induction of inflammation in these studies to prevent mortality due to sepsis in neutropenic mice. Histology demonstrated that the massive infiltration of leukocytes, predominantly PMNs, as observed in immunocompetent mice was absent in neutropenic mice (data not shown). The biodistribution of ${ }^{125} \mathrm{I}-\mathrm{IL}-1 \alpha$ in immunocompetent $(n=25)$ and neutropenic mice $(n=25)$, determined at various times after intravenous injection of 0.4 $\mathrm{MBq} 120 \mathrm{ng}$ of the radiolabeled preparation, was similar (Table I). ${ }^{125}$ I-IL-1 $\alpha$ rapidly cleared from most organs. However, one major difference was observed: ${ }^{125} \mathrm{I}-\mathrm{IL}-1 \alpha$ was retained at the site of inflammation in immunocompetent mice, while virtually no retention of ${ }^{125} \mathrm{I}-\mathrm{IL}-1 \alpha$ in the inflammation was found in neutropenic mice (Fig. 5). At all time points, the uptake of ${ }^{125}$ I-IL- $1 \alpha$ at the site of inflammation was significantly higher in immunocompetent mice than in neutropenic mice $(P<$ 0.001). Maximum differences were obtained at $48 \mathrm{~h}$ after injection; the uptake of ${ }^{125}$ I-IL- $1 \alpha$ in inflammation was $>12$ times higher in immunocompetent mice compared with neutropenic mice, $0.65 \pm 0.06$ and $0.05 \pm 0.004 \% \mathrm{ID} / \mathrm{g}$, respectively.

Effect of in vivo blockade of IL-1Rs on localization of ${ }^{125}$ I-IL-1 $\alpha$ in inflammation. To elucidate whether type I and/ or type II IL-1R is/are involved in entrapment of radioiodinated IL- $1 \alpha$ in inflammation, groups of five mice with $S$. $a u$ reus-induced inflammations were injected intravenously with $200 \mu \mathrm{g}$ anti-type I IL-1R antibody 35F5, $200 \mu \mathrm{g}$ anti-type II IL-1R antibody 4E2, or a mixture of both antibodies $(200 \mu \mathrm{g}$ of each antibody) in $100 \mu \mathrm{l}$ sterile saline at $6 \mathrm{~h}$ and $5 \mathrm{~min}$ before intravenous injection of $0.4 \mathrm{MBq} 120 \mathrm{ng}{ }^{125} \mathrm{I}-\mathrm{IL}-1 \alpha$. Control mice $(n=5)$ were injected intravenously with $100 \mu$ l sterile saline before injection of ${ }^{125} \mathrm{I}-\mathrm{IL}-1 \alpha$. As depicted in Fig. 6, mice with type I IL-1R blockade displayed significantly higher uptake of ${ }^{125} \mathrm{I}-\mathrm{IL}-1 \alpha$ in the inflammation than the control group, i.e., $2.26 \pm 0.12$ vs. $0.65 \pm 0.05 \% \mathrm{ID} / \mathrm{g}$ at $48 \mathrm{~h}$ after injection $(P<0.0001)$. In contrast, the uptake of ${ }^{125}$ I-IL- $1 \alpha$ at the site of inflammation in mice with blockade of type II IL-1Rs $(0.13 \pm 0.009)$ was significantly lower than the value obtained in control mice $(P<0.0001)$. A similar low uptake of $0.14 \pm$ $0.009 \% \mathrm{ID} / \mathrm{g}$ in inflammation was found in mice with both type I and type II IL-1R blockade. The ${ }^{125}$ I-IL-1 $\alpha$ levels in the blood and all other organs were similar for all studied groups (data not shown).

\section{Discussion}

This study confirms the hypothesis that systemically administered radiolabeled IL- $1 \alpha$ localizes in acute inflammatory foci by specific receptor binding. As demonstrated by microscopic autoradiography, IL- $1 \alpha$ localized within the inflammation at the site of the infiltrated leukocytes, which were predomi- 

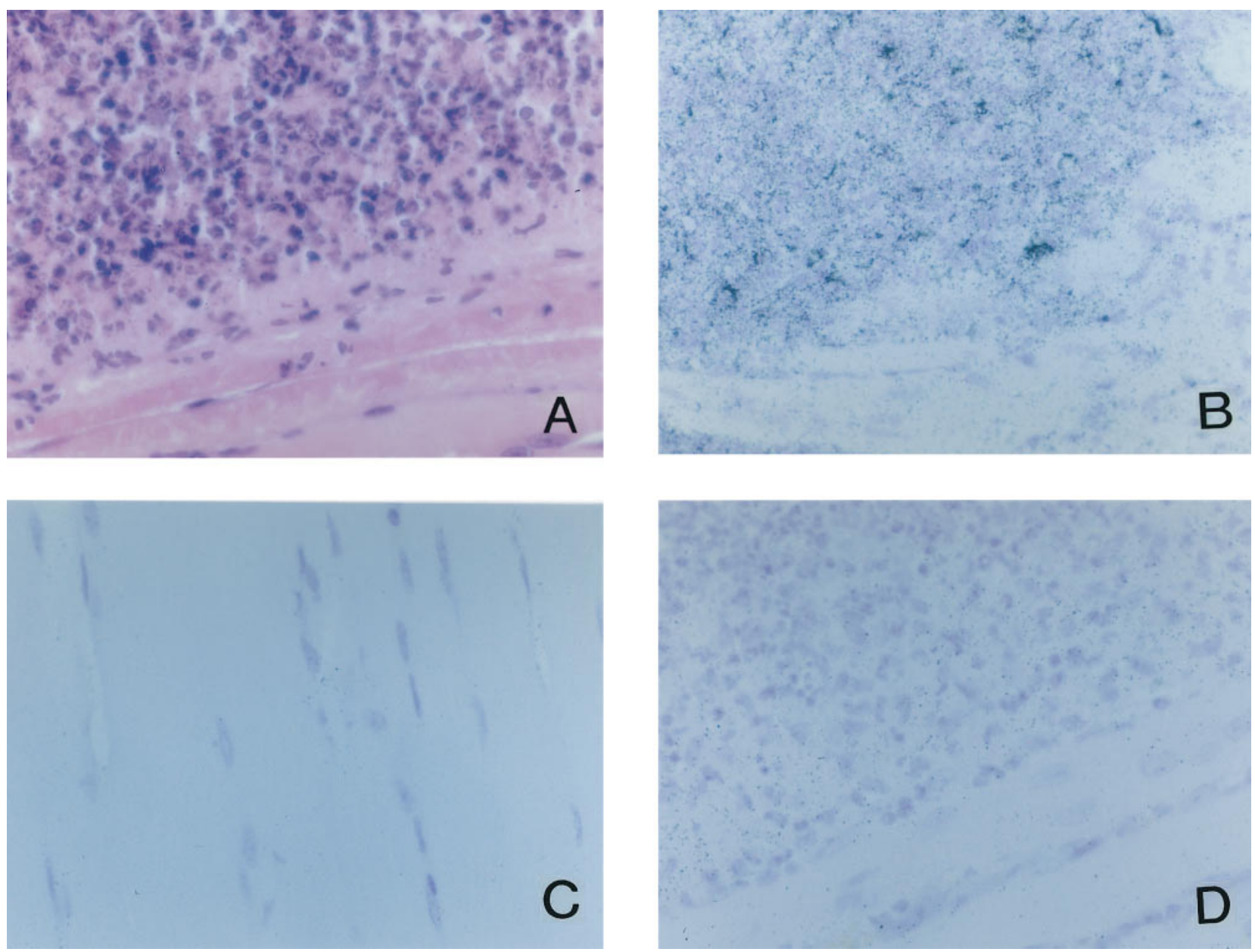

Figure 3. Microscopic autoradiography of inflammatory tissue of a mouse $24 \mathrm{~h}$ after injection with ${ }^{125} \mathrm{I}-\mathrm{IL}-1 \alpha$, without photographic emulsion (hematoxylin and eosin, $\times 400)(A)$ and approximately the same area with photographic emulsion (hematoxylin, $\times 400)(B)$. $(C)$ The corresponding contralateral muscle with photographic emulsion (hematoxylin, $\times 400$ ). (D) Inflammatory tissue with photographic emulsion of a mouse $24 \mathrm{~h}$ after injection of the control agent ${ }^{125}$ I-myoglobin (hematoxylin, $\times 400$ ).

nantly PMNs. The studies with neutropenic mice corroborated these findings, since low uptake of IL-1 $\alpha$ in inflammation was found in the absence of cellular infiltration. Moreover, the IL-1 receptor blockade studies showed that the retention of IL-1 $\alpha$ in inflammatory tissue was inhibited by blockade of type II IL-1Rs.

The binding of human recombinant IL-1 to murine leukocytes, predominantly PMNs, has also been described by Parker et al. (4). In their studies in mice, PMNs were removed from peritoneal exudate to test the binding of radiolabeled IL- 1 to these cells ex vivo. Our results show binding of systemically administered radiolabeled IL-1 to murine infiltrated leukocytes in acute inflammation in vivo. The receptor binding capacity of IL-1 after radiolabeling was tested in vitro on murine thymoma cells. The affinity was as high as reported in earlier studies $(2,5)$. It was not possible to isolate leukocytes from the inflammatory tissue in mice to test the binding to these cells ex vivo. Therefore, microscopic autoradiography was used to visualize the localization of ${ }^{125}$ I-IL-1 $\alpha$ in the cellular infiltration of inflammatory tissue. This method has also been used by others to identify IL-1 receptors in various noninflamed murine tissues $(14,15)$. To exclude nonspecific accumulation in in- flammatory foci by locally increased vascular permeability (16-18), inflammatory tissue of mice injected with the control agent ${ }^{125}$ I-myoglobin was also subjected to microscopic autoradiography, showing no localization in the cellular infiltration. This indicates that IL-1 $\alpha$ is retained in inflammatory foci by specific binding to its receptors.

For most of our studies, $S$. aureus-induced focal infections were used. These infections are characterized by massive inflammatory cell infiltration. Mice with a focal $S$. aureus infection do not show general signs of illness. However, neutropenic mice with such infections become severely ill and die within 1-3 d, most likely due to sepsis. To allow comparison of uptake of radiolabeled IL- $1 \alpha$ in inflammation in neutropenic and immunocompetent mice, the sterile zymosan model was chosen, which in immunocompetent mice induces a massive focal infiltration of PMNs and monocytes $(19,20)$. Neutropenic mice with zymosan-induced inflammations did not show any signs of illness. No cellular infiltration was found in the induced inflammations of these mice. Despite similar biodistribution in both groups of mice, the uptake of ${ }^{125}$ I-IL-1 $\alpha$ at the site of inflammation was significantly higher in immunocompetent mice, again stressing the fact that radiolabeled IL-1 $\alpha$ accu- 


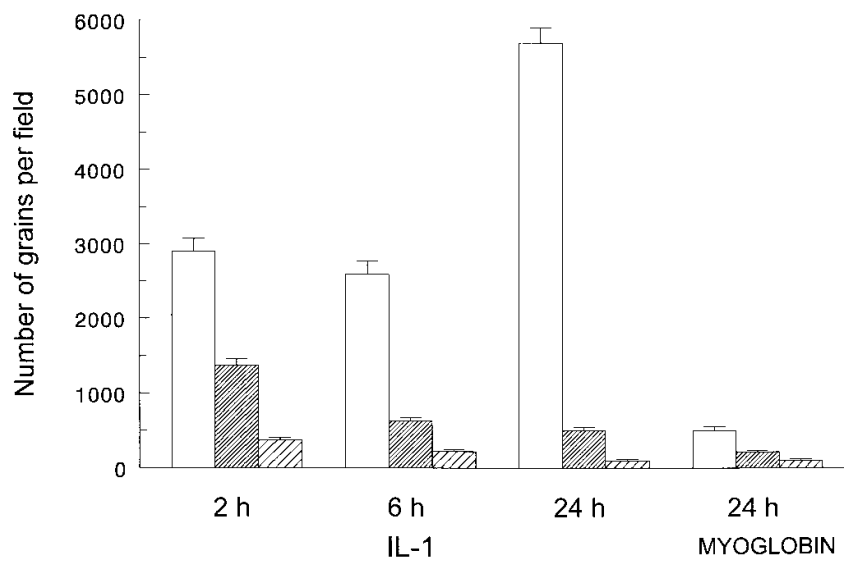

Figure 4. The quantitative analysis of microscopic autoradiography of inflammation (infiltration, open bars, and adjacent muscle, heavily striped bars) and contralateral muscle (striped bars) sections of mice injected with either ${ }^{125} \mathrm{I}-\mathrm{IL}-1 \alpha$ or ${ }^{125} \mathrm{I}$-myoglobin (at $24 \mathrm{~h}$ after injection only), expressed as mean number of grains per field \pm SEM.

mulates in inflammatory tissue by means of binding to its receptors on infiltrated leukocytes.

The IL-1R blockade studies showed that the binding of radiolabeled IL-1 $\alpha$ to infiltrated leukocytes was mainly due to binding to type II IL-1Rs. The inflammation uptake of IL-1 $\alpha$ was significantly lower in case of blockade of type II IL-1Rs. Surprisingly, increased uptake of radiolabeled IL- $1 \alpha$ in the inflammation was found when type I IL-1Rs were blocked. Blockade of type I IL-1Rs, expressed on a wide range of cells in the body, may have increased levels of free IL- $1 \alpha$, available for binding to type II IL-1Rs, expressed on infiltrated neutrophils and monocytes in the inflammation. When both type I and type II IL-1Rs were blocked, inflammation uptake of IL-1 $\alpha$ was as low as that found with type II IL-1R blockade only. This indicates that the increased uptake of IL-1 $\alpha$ in inflamma-

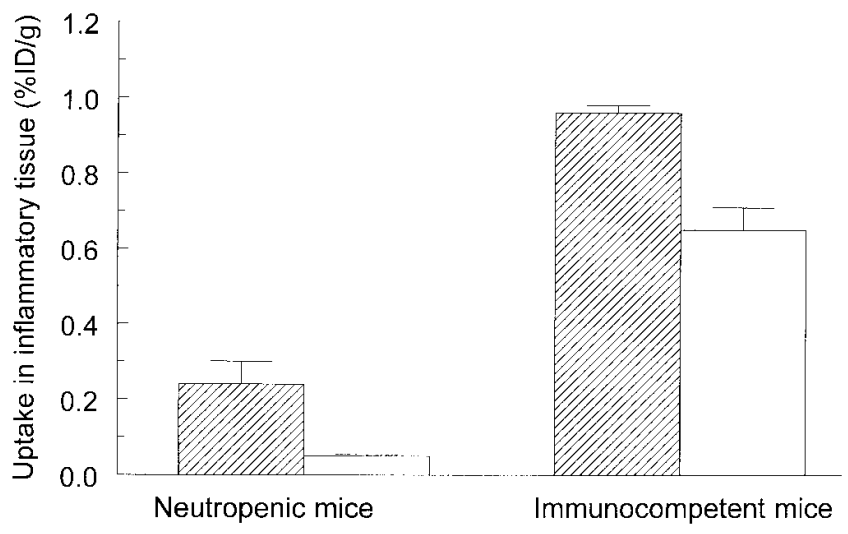

Figure 5. The uptake of ${ }^{125}$ I-IL-1 $\alpha$ in zymosan-induced inflammation in neutropenic and immunocompetent mice at 24 (striped bars) and $48 \mathrm{~h}$ (open bars) after injection. The results are expressed as percentages of injected radioactivity dose per gram of tissue (\% ID/g). The error bars indicate SEM. tory tissue (obtained by blockade of type I IL-1Rs) could be completely inhibited by blockade of type II IL-1Rs. Therefore, aspecific increased uptake of IL- $1 \alpha$ in inflammation in case of type I IL-1R blockade could be ruled out. Binding to soluble type II IL-1Rs, increased during various inflammatory conditions (21-23), could also be excluded since the used anti-type II antibody 4E2 also binds and neutralizes these receptors.

Although blockade of binding of radiolabeled IL- $1 \alpha$ to type II IL-1Rs with the antibody 4E2 has been demonstrated in vitro on cell lines (24), in vivo, blockade of type II IL-1Rs did not affect particular studied biologic effects of IL-1 $\alpha$ (7, 10). Since it is now generally accepted that the type II IL-1R acts as a decoy receptor for IL-1 (25-28), no direct effects of type II IL-1R blockade on IL-1 induced biologic activity are to be expected. Indirectly, type II IL-1R blockade may enhance

Table I. Biodistribution of ${ }^{125}$ I-IL-1 $\alpha$ in Neutropenic and Immunocompetent Mice with Zymosan-induced Inflammation

\begin{tabular}{|c|c|c|c|c|c|c|}
\hline Organ & Neutropenia & 2 h p.i.** & 6 h p.i. & 12 h p.i. & 24 h p.i. & 48 h p.i. \\
\hline \multirow[t]{2}{*}{ Blood } & + & $4.79 \pm 0.19$ & $2.12 \pm 0.12$ & $0.52 \pm 0.12$ & $0.18 \pm 0.01$ & $0.04 \pm 0.004$ \\
\hline & - & $4.10 \pm 0.33$ & $1.49 \pm 0.13$ & $0.28 \pm 0.009$ & $0.13 \pm 0.01$ & $0.08 \pm 0.009$ \\
\hline \multirow[t]{2}{*}{ Inflammation } & + & $1.67 \pm 0.14$ & $0.96 \pm 0.06$ & $0.36 \pm 0.04$ & $0.24 \pm 0.06$ & $0.05 \pm 0.004$ \\
\hline & - & $2.90 \pm 0.17$ & $2.20 \pm 0.05$ & $1.33 \pm 0.14$ & $0.96 \pm 0.02$ & $0.65 \pm 0.06$ \\
\hline \multirow[t]{2}{*}{ Muscle } & + & $0.77 \pm 0.04$ & $0.36 \pm 0.04$ & $0.08 \pm 0.02$ & $0.04 \pm 0.006$ & $0.01 \pm 0.002$ \\
\hline & - & $1.18 \pm 0.40$ & $0.25 \pm 0.02$ & $0.08 \pm 0.004$ & $0.04 \pm 0.002$ & $0.02 \pm 0.004$ \\
\hline \multirow[t]{2}{*}{ Thymus } & + & $2.35 \pm 0.28$ & $1.46 \pm 0.23$ & $0.35 \pm 0.10$ & $0.14 \pm 0.01$ & $0.07 \pm 0.02$ \\
\hline & - & $1.38 \pm 0.22$ & $0.85 \pm 0.21$ & $0.24 \pm 0.03$ & $0.12 \pm 0.02$ & $0.06 \pm 0.004$ \\
\hline \multirow[t]{2}{*}{ Lung } & + & $3.89 \pm 0.23$ & $1.86 \pm 0.06$ & $0.49 \pm 0.14$ & $0.18 \pm 0.01$ & $0.06 \pm 0.008$ \\
\hline & - & $5.32 \pm 0.70$ & $1.45 \pm 0.02$ & $0.31 \pm 0.02$ & $0.14 \pm 0.006$ & $0.11 \pm 0.02$ \\
\hline \multirow[t]{2}{*}{ Spleen } & + & $4.70 \pm 0.25$ & $1.44 \pm 0.10$ & $0.38 \pm 0.10$ & $0.15 \pm 0.006$ & $0.06 \pm 0.004$ \\
\hline & - & $4.68 \pm 0.64$ & $1.36 \pm 0.11$ & $0.35 \pm 0.05$ & $0.14 \pm 0.03$ & $0.07 \pm 0.009$ \\
\hline \multirow[t]{2}{*}{ Liver } & + & $4.67 \pm 0.25$ & $1.26 \pm 0.06$ & $0.38 \pm 0.06$ & $0.19 \pm 0.02$ & $0.10 \pm 0.004$ \\
\hline & - & $3.26 \pm 0.28$ & $0.91 \pm 0.10$ & $0.32 \pm 0.01$ & $0.19 \pm 0.01$ & $0.16 \pm 0.009$ \\
\hline \multirow[t]{2}{*}{ Kidney } & + & $5.27 \pm 0.26$ & $1.79 \pm 0.09$ & $0.58 \pm 0.10$ & $0.27 \pm 0.01$ & $0.16 \pm 0.008$ \\
\hline & - & $4.67 \pm 0.45$ & $1.25 \pm 0.14$ & $0.41 \pm 0.02$ & $0.26 \pm 0.006$ & $0.18 \pm 0.01$ \\
\hline
\end{tabular}

*All values are expressed as percentage of injected dose per gram of tissue. p.i., postinjection. 


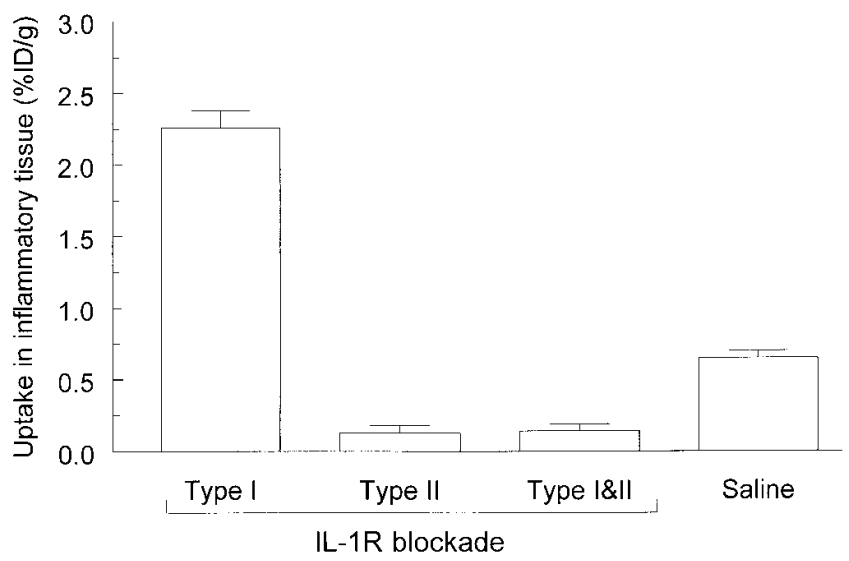

Figure 6. The uptake of ${ }^{125}$ I-IL-1 $\alpha$ in inflammation at $48 \mathrm{~h}$ after injection in mice in which IL-1Rs were blocked with anti-IL-1R type I antibodies, anti-IL-1R type II antibodies, or both IL-1R type I and type II antibodies before injection of ${ }^{125} \mathrm{I}-\mathrm{IL}-1 \alpha$. Control mice were injected with saline before injection of ${ }^{125} \mathrm{I}-\mathrm{IL}-1 \alpha$. The results are expressed as percentages of injected radioactivity dose per gram of tissue $(\% \mathrm{ID} / \mathrm{g})$. The error bars indicate SEM.

IL-1-induced biologic activity, as shown by others in vitro (25, 26), but this may be more difficult to demonstrate in vivo. The effects of type II IL-1R blockade on IL-1-induced biologic activity were not evaluated, but the inhibition of receptor binding of radiolabeled IL- $1 \alpha$ at the site of inflammation by type II IL-1R blockade could be shown in vivo.

The uptake of IL-1 $\beta$ in inflammation was lower than the uptake of IL- $1 \alpha$. Apparently, lower amounts of IL-1 $1 \beta$ bound to IL-1Rs in the inflammatory tissue. Since systemically administered IL-1 appears to mainly bind to type II IL-1Rs, these findings are in line with data obtained by Parker et al. (4). They also tested the binding of human recombinant IL-1 $\alpha$ and IL-1 $\beta$ for the type II IL-1R on murine PMNs and found a twoto threefold lower affinity for IL- $1 \beta$ as compared with IL- $1 \alpha$. Opposite results have been reported for the binding of human recombinant IL- $1 \alpha$ and IL- $1 \beta$ to the human type II IL-1R (29, 30 ), indicating that species differences play a role in receptorbinding characteristics of IL- $1 \alpha$ and IL- $1 \beta$.

Although the total amount of radiolabeled IL- $1 \alpha$ in the inflammation decreased with time, retention was still found at $48 \mathrm{~h}$ after injection. Most likely, as demonstrated by the microscopic autoradiography results, IL- $1 \alpha$ accumulates in inflammatory tissue shortly after injection and migrates toward the binding sites on infiltrated leukocytes during the next $24-48 \mathrm{~h}$. Some IL- $1 \alpha$ molecules will bind easily accessible receptors early after injection and others reach binding sites several hours thereafter. After $24 \mathrm{~h}$, radiolabeled IL- $1 \alpha$, retained in the inflammation, could almost only be found in areas of cellular infiltration. In the meantime, most of the unbound and/or degraded IL- $1 \alpha$ is cleared from the tissue, resulting in a decreasing total amount of radiolabeled IL- $1 \alpha$ in the inflammation. Despite the latter, the uptake in areas of cellular infiltration even increased with time, which could be explained by the fact that these areas form the minority of the total inflammation. Since IL-1 $\alpha$ seemed to bind mainly to type II IL-1Rs in the models of inflammation studied, these observations may be conflicting with data suggesting poor internalization of re- ceptor-bound IL-1 (31) and a fast turnover of the receptor ( $2 \mathrm{~h})$ (32). However, these characteristics were observed in vitro using the Raji human B lymphoma cell line. In vivo, IL-1 binding to type II receptors on activated leukocytes in inflammatory tissue may be different.

This study supports first indications that systemically administered radiolabeled IL- $1 \alpha$ localizes in inflammation by specific receptor binding. The type II IL-1R appeared to be the predominant binding site in acute inflammation models. Actual binding of IL- $1 \alpha$ to type II IL-1R in inflammatory tissue could be demonstrated. Future studies will focus on the in vivo behavior of IL-1 $\alpha$ and the correlation with IL-1R expression in various other inflammation models.

\section{Acknowledgments}

The authors thank C. Diepenbroek and L. Schalkwijk (University of Nijmegen, Department of Pathology) for technical assistance in the microscopic autoradiography studies, P. Mast for determination of the leukocyte counts to establish neutropenia (University of Nijmegen, Department of Hematology), and G. Grutters, H. Eijkholt, and Y. Brom (University of Nijmegen, Central Animal Laboratory) for technical assistance in all the studies with mice.

\section{References}

1. Dinarello, C.A. 1991. Interleukin-1 and interleukin-1 antagonism. Blood. 77:1627-1652

2. Lowenthal, J.W., and H.R. MacDonald. 1986. Binding and internalization of interleukin 1 by T cells. J. Exp. Med. 164:1060-1074.

3. Van der Laken, C.J., O.C. Boerman, W.J.G. Oyen, M.T.P. van de Ven, R.A.M.J. Claessens, J.W.M. van der Meer, and F.H.M. Corstens. 1995. Specific targeting of infectious foci with radioiodinated human recombinant interleukin-1 in an experimental model. Eur. J. Nucl. Med. 22:1249-1255.

4. Parker, K.P., W.R. Benjamin, K.L. Kaffka, and P.L. Kilian. 1989. Presence of IL-1 receptors on human and murine neutrophils: relevance to IL-1 mediated effects in inflammation. J. Immunol. 142:537-542.

5. Chizzonite, R., T. Truitt, and P.L. Kilian. 1989. Two high-affinity interleukin-1 receptors represent separate gene products. Proc. Natl. Acad. Sci. USA. 86:8029-8033.

6. McIntyre, K.W., G.J. Stepan, K.D. Kolinsky, W.R. Benjamin, J.M. Plocinsky, K.L. Kaffka, C.A. Campen, R.A. Chizzonite, and P.L. Kilian. 1991. Inhibition of interleukin 1 (IL-1) binding and bioactivity in vitro and modulation of acute inflammation in vivo by IL-1 receptor antagonist and anti-IL-1 receptor monoclonal antibody. J. Exp. Med. 173:931-939.

7. Hestdal, K., S.E. Jacobsen, F.W. Ruscetti, C.M. Dubois, D.L. Longo, R. Chizzonite, J.J. Oppenheim, and J.R. Keller. 1992. In vivo effect of interleukin-1 alpha on hematopoiesis: role of colony-stimulating factor receptor modulation. Blood. 80:2486-2494.

8. Dubois, C.M., F.W. Ruscetti, J.R. Keller, J.J. Oppenheim, K. Hestdal, R. Chizzonite, and R. Neta. 1991. In vivo interleukin-1 (IL-1) administration indirectly promotes type II IL-1 receptor expression on hematopoietic bone marrow cells: novel mechanism for the hematopoietic effects of IL-1. Blood. 78: 2841-2847.

9. Neta, R., S.N. Vogel, J.M. Plocinsky, N.S. Tare, W. Benjamin, R. Chizzonite, and M. Pilcher. 1990. In vivo modulation with anti-interleukin-1 (IL-1) receptor (p80) antibody $35 \mathrm{~F} 5$ of the response to IL-1. The relationship of radioprotection, colony-stimulating factor, and IL-6. Blood. 76:57-62.

10. Oldenburg, H.S., J.H. Pruitt, D.D. Lazarus, M.A. Rogy, R. Chizzonite, S.F. Lowry, and L.L. Moldawer. 1995. Interleukin-1 binding to its type I, but not to type II receptor, modulates the in vivo acute phase response. Cytokine. 7 : 510-516.

11. Fraker, P.J., and J.C. Speck. 1978. Protein and cell membrane iodination with a sparingly soluble chloramide 1,3,4,6-tetrachloro- $3 \alpha, 6 \alpha$-diphenyl-glucouril. Biochem. Biophys. Res. Commun. 80:849-857.

12. Zubler, R.H., F. Erard, R.K. Lees, M. van Laer, C. Mingari, L. Moretta, and H.R. MacDonald. 1985. Mutant EL-4 thymoma cells polyclonally activate murine and human B cells via direct cell interaction. J. Immunol. 134:3662.

13. Tamimi, Y., H.G. van der Poel, M.M. Denyn, R. Umbas, H.F. Karthaus, F.M. Debruyne, and J.A. Schalken. 1993. Increased expression of high mobility group protein $\mathrm{I}(\mathrm{Y})$ in high-grade prostatic cancer determined by in situ hybridization. Cancer Res. 53:5512-5516.

14. Takao, T., W.M. Mitchell, D.E. Tracey, and E.B. De Souza. 1990. Identification of interleukin-1 receptors in mouse testis. Endocrinology. 127:251258. 
15. Takao, T., W.M. Mitchell, and E.B. De Souza. 1991. Interleukin-1 receptors in mouse kidney: identification, localization, and modulation by lipopolysaccharide treatment. Endocrinology. 128:2618-2624.

16. Lavender, J.P., J. Lowe, J.R. Barker, J.I. Burn, and M.A. Chaudri. 1971. Gallium-67 citrate scanning in neoplastic and inflammatory lesions. Br. J. Radiol. 44:361-366.

17. McAfee, J.G., G. Gagne, G. Subramanian, and R.F. Schneider. 1991. The localization of indium-111-leucocytes, gallium-67, polyclonal IgG and other radioactive agents in acute focal inflammatory lesions. J. Nucl. Med. 32: 2126-2131.

18. Oyen, W.J.G., R.A.M.J. Claessens, J.W.M. van der Meer, and F.H.M. Corstens. 1992. Biodistribution and kinetics of radiolabeled proteins in rats with focal infection. J. Nucl. Med. 33:388-393.

19. Lefkowith, J.B. 1988. Essential fatty acid deficiency inhibits the in vivo generation of leukotriene B4 and suppresses levels of resident and elicited leukocytes in acute inflammation. J. Immunol. 140:228-233.

20. Dawson, J., A.D. Sedgewick, J.C. Edwards, and P. Lees. 1991. A comparative study of the cellular, exudative and histological responses to carrageenan, dextran and zymosan in the mouse. Int. J. Tissue React. 13:171-185.

21. Symons, J.A., J.A. Eastgate, and G.W. Duff. 1990. A soluble binding protein specific for interleukin-1 beta is produced by activated mononuclear cells. Cytokine. 2:190-198.

22. Giri, J.G., J. Wells, S.K. Dower, C.E. McCall, R.N. Guzman, J. Slack, T.A. Bird, K. Shaneback, K.H. Grabstein, J.E. Sims, and M.R. Alderson. 1994. Elevated levels of shed type II IL-1 receptor in sepsis. J. Immunol. 153:58025809.

23. Arend, W.P., M. Malyak, M.F. Smith, T.D. Whisenand, J.L. Slack, J.E. Sims, J.G. Giri, and S.K. Dower. 1994. Binding of IL-1 $\alpha$, IL-1 $\beta$, and IL-1 receptor antagonist by soluble IL-1 receptors and levels of soluble IL-1 receptors in synovial fluids. J. Immunol. 153:4766-4774.

24. Hestdal, K., F.W. Ruscetti, R. Chizzonite, M. Ortiz, J.M. Gooya, D.L.
Longo, and J.R. Keller. 1994. Interleukin-1 (IL-1) directly and indirectly promotes hematopoietic cell growth through type I IL-1 receptor. Blood. 1:125132 .

25. Colotta, F., F. Re, M. Muzio, R. Bertini, N. Polentarutti, M. Sironi, J.G. Giri, S.K. Dower, J.E. Sims, and A. Mantovini. 1993. Interleukin-1 type II receptor: a decoy target for IL-1 that is regulated by IL-4. Science. 261:472-475.

26. Sims, J.E., M.A. Gayle, J.L. Slack, M.R. Alderson, T.A. Bird, J.G. Giri, F. Colotta, F. Re, A. Mantovani, K. Shanebeck, K.H. Grabstein, and S.K Dower. 1993. Interleukin-1 signaling occurs exclusively via the type I receptor. Proc. Natl. Acad. Sci. USA. 90:6155-6159.

27. Colotta, F., S.K. Dower, J.E. Sims, and A. Mantovini. 1994. The type II "decoy" receptor: a novel regulatory pathway for interleukin-1. Immunol. Today. 15:562-566.

28. Re, F., M. Sironi, and M. Muzio. 1996. Inhibition of interleukin 1 responsiveness by type II receptor gene transfer: a surface "receptor" with antiinterleukin 1 function. J. Exp. Med. 183:1841-1850.

29. Scapigliati, G., P. Ghiari, M. Bartalini, A. Tagliabue, and D. Boraschi. 1989. Differential binding of IL- $1 \alpha$ and IL-1 $\beta$ to receptors on B and T cells. FEBS Lett. 243:394-398.

30. Re, F., M. Muzio, M. De Rossi, N. Polentarutti, J.G. Giri, A. Mantovani, and F. Colotta. 1994. The type II "receptor" as a decoy target for interleukin 1 in polymorphonuclear leukocytes: characterization of induction by dexamethasone and ligand binding properties of the released decoy receptor. J. Exp. Med. 179:739-743.

31. Horuk, R., J.J. Huang, M. Covington, and R.C. Newton. 1987. A biochemical and kinetic analysis of the interleukin-1 receptor. Evidence for differences in molecular properties of IL-1 receptors. J. Biol. Chem. 262:1627516278.

32. Horuk, R., and J.A. McCubrey. 1989. The interleukin-1 receptor in Raji human B-lymphoma cells. Molecular characterization and evidence for receptor-mediated activation of gene expression. Biochem. J. 260:657-663. 